University of Wollongong

Research Online

Faculty of Engineering and Information

Faculty of Engineering and Information

Sciences - Papers: Part B

Sciences

2020

\title{
Numerical simulation of strip shape of high-strength steel during hot rolling process
}

\author{
Lianjie Li \\ University of Wollongong, II940@uowmail.edu.au \\ Haibo Xie \\ University of Wollongong, xie@uow.edu.au \\ Xu Liu \\ Tianwu Liu \\ University of Wollongong, tianwu@uow.edu.au \\ Enrui Wang
}

See next page for additional authors

Follow this and additional works at: https://ro.uow.edu.au/eispapers1

Part of the Engineering Commons, and the Science and Technology Studies Commons

Research Online is the open access institutional repository for the University of Wollongong. For further information contact the UOW Library: research-pubs@uow.edu.au 


\title{
Numerical simulation of strip shape of high-strength steel during hot rolling process
}

\author{
Abstract \\ 2020 Trans Tech Publications Ltd, Switzerland. High-strength steel is widely applied due to its excellent \\ mechanical properties. However, its high strength in turn brings great difficulties to production and \\ processing such as hot strip rolling owing to the high rolling force, which results in large elastic \\ deformation of roll stack and poses a huge challenge to the control of strip crown and flatness. In this \\ paper, A threedimensional (3D) elastic-plastic coupled thermo-mechanical finite element (FE) model for \\ hot strip rolling of high-strength steel is developed and then verified experimentally. This model not only \\ calculates the elastic deformation of rolls and plastic deformation of strip simultaneously, but also \\ considers the effect of temperature variation during hot strip rolling. Based on this valid model, the \\ effects of bending force and shifting value of work roll (WR), back-up roll (BR) size, entrance strip crown \\ and rolling force on strip crown have been investigated quantitatively. The results obtained provide \\ valuable guidelines for industrial strip production.

\section{Disciplines} \\ Engineering | Science and Technology Studies

\section{Publication Details} \\ Li, L., Xie, H., Liu, X., Liu, T., Wang, E. \& Jiang, Z. (2020). Numerical simulation of strip shape of high- \\ strength steel during hot rolling process. Key Engineering Materials, 830 KEM 43-51.
}

\section{Authors}

Lianjie Li, Haibo Xie, Xu Liu, Tianwu Liu, Enrui Wang, and Zhengyi Jiang 


\title{
Numerical simulation of strip shape of high- strength steel during hot rolling Process
}

\author{
Lianjie $\mathrm{Li}^{1}$, Haibo $\mathrm{Xie}^{1}$, Xu $\mathrm{Liu}^{2}$, Tianwu $\mathrm{Liu}^{2}$, Enrui $\mathrm{Wang}^{2}$, and Zhengyi Jiang ${ }^{1,3, *}$
}

${ }^{1}$ School of Mechanical, Materials, Mechatronic and Biomedical Engineering, Faculty of Engineering and Information Sciences, University of Wollongong, 2522, Australia

${ }^{2}$ Iron \& Steel Research Institute, Hesteel Group, Shijiazhuang, 050023, China

${ }^{3}$ School of Materials and Metallurgy, University of Science and Technology, Liaoning, Anshan, 114051, China

\begin{abstract}
High-strength steel is widely applied due to its excellent mechanical properties. However, its high strength in turn brings great difficulties to production and processing such as hot strip rolling owing to the high rolling force, which results in large elastic deformation of roll stack and poses a huge challenge to the control of strip crown and flatness. In this paper, A three-dimensional (3D) elastic-plastic coupled thermo-mechanical finite element (FE) model for hot strip rolling of high-strength steel is developed and then verified experimentally. This model not only calculates the elastic deformation of rolls and plastic deformation of strip simultaneously, but also considers the effect of temperature variation during hot strip rolling. Based on this valid model, the effects of bending force and shifting value of work roll (WR), back-up roll (BR) size, entrance strip crown and rolling force on strip crown have been investigated quantitatively. The results obtained provide valuable guidelines for industrial strip production.
\end{abstract}

\section{Introduction}

With the development of automotive lightweight, high quality advanced high strength steels (AHSSs) are required to meet performance demands of the automotive parts [1]. It is known that most AHSSs are produced through hot strip rolling or subsequent cold strip rolling. This poses a huge challenge to strip shape control due to the high rolling force caused by the large deformation resistance of AHSSs and large reduction ratio in hot strip rolling. However, the

\footnotetext{
* Corresponding author: jiang@uow.edu.au
} 
crown and flatness of hot rolled strip are vital quality indicators for subsequent cold strip rolling and downstream users. Therefore, it is important to study the influence factors on strip crown and optimise the process parameters during hot strip rolling.

In the past decades, a number of researcher have made a contribution on strip rolling research by finite element method (FEM). A 2D FE model was developed for hot flat rolling analysis by rigid-plastic finite element method (RPFEM) [2,3]. Jiang et al [4,5] studied the ribbed-strip rolling using rigid-viscoplastic FEM. Kim et al [6] proposed an integrated FE model for the coupled analysis of the mechanical behavior of the strip and rolls in four-high mill. Zhang et al [7] calculated the plastic deformation of strip, deflection and flattening of roll in strip hot rolling by combining RPFEM and elastic-plastic FEM with influential function method (IFM). Linghu et al [8,9] investigated the strip shape during multi-pass rolling in a 6-high CVC cold rolling mill through a 3D elastic-plastic FE model.

Aljabri et al [10] simulated the asymmetrical strip rolling using WR cross and WR shifting by FEM. Wang et al $[11,12]$ studied the actuator efficiency factors for UCM cold rolling mill using an elastic-plastic FEM.

In this study, a 3D elastic-plastic coupled thermo-mechanical FE model of hot strip rolling is developed and verified by rolling experiments. The effects of bending force and shifting value of WR, BR size, entrance strip crown and rolling force on strip crown will be studied in detail and their the influence ratios are calculated respectively.

\section{FE model of hot strip rolling}

In this study, a 3D elastic-plastic coupled thermo-mechanical FE model for a hot 4-high mill is established based on MSC Marc software. The flow stress curves of strip material are regressed by GMT-1 constitutive equation. In addition, the developed FE model is verified through comparing simulated rolling force and rolled strip crown with measured data.

\subsection{Geometry model and meshing strategy}

3rd order continuous variable crown (CVC) curve is used to describe the contour of work roll along width direction. Varying contact length back-up roll (VCR) is adopted to eliminate the harmful contact area between WR and BR, and enhance the transverse stiffness of loaded roll gap [13].

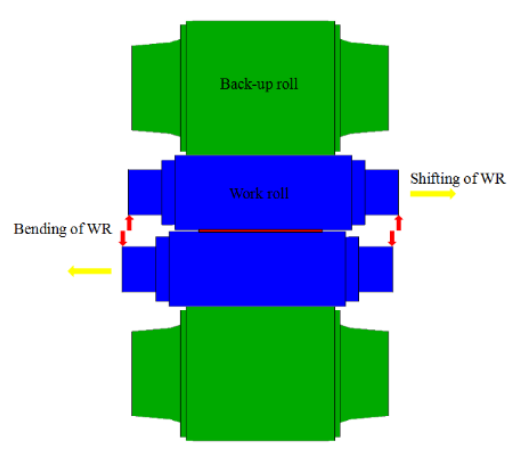

Fig. 1. Sketch map of 4-high mill model.
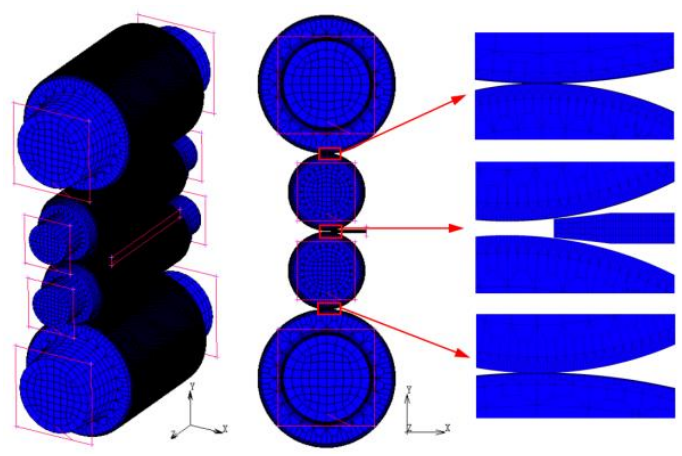

Fig. 2. FE model of hot strip rolling. 
Fig. 1 shows the geometry model of 4-high rolling mill. The movement of work roll involves two parts: shifting in transverse direction and bending in vertical direction. The geometry model of 4-high mill is divided into 8 nodes hexahedral elements, as shown in Fig. 2. In order to improve the computation efficiency and accuracy, the contact areas between rolls and strip are refined. This model contains 228,312 elements and 290,935 nodes totally. The movements of WR and BR are controlled via the rigid surfaces, which are glued with elements of rolls. Strip is pushed into roll gap by a moving rigid surface at a speed of $0.5 \mathrm{~m} / \mathrm{s}$. Furthermore, the implicit method is adopted to improve the calculation accuracy of elastic deformation.

\subsection{Material model}

In this FE model, the strip and rolls are treated as elastic-plastic material and elastic material, respectively. One typical high-strength steel FL590 is selected as strip material. BR and WR are made of $\mathrm{Cr} 5$ forged steel and high chromium cast iron, respecctively.

In order to establish the constitutive equation of strip material, hot compression experiment is conducted on the Gleeble 3800 Thermal Simulator. The true stress increases obviously with the increase of strain rate and the decrease of deformation temperature. The true stresstrue strain curves obtained can be expressed by the GMT-1 constitutive equation, as shown in Eq. (1). To increase the accuracy of fitting curves, the deformation temperature can be divided into three ranges: $\mathrm{T} \leq 900^{\circ} \mathrm{C}, 900^{\circ} \mathrm{C}<\mathrm{T}<1000^{\circ} \mathrm{C}, \mathrm{T} \geq 1000^{\circ} \mathrm{C}$. The corresponding material parameters of the constitutive equation are listed in Table 1.

$$
\sigma_{y}=A \cdot P_{1} \cdot e^{P_{2} T} \cdot T^{P_{9}} \cdot \varepsilon_{p}^{P_{3}} \cdot e^{\frac{P_{5}}{\varepsilon_{p}}+P_{7} \varepsilon_{p}} \cdot\left(1+\varepsilon_{p}\right)^{P_{6} T} \cdot \dot{\varepsilon}_{p}^{P_{4}+P_{8} T}
$$

where $\sigma_{y}$ is yield stress (MPa), $A$ is scale coefficient, which is set as 1.0 in this paper, $P_{1}$, $P_{2}, P_{3}, P_{4}, P_{5}, P_{6}, P_{7}, P_{8}$ are material parameters, $\varepsilon_{p}$ is equivalent plastic strain, $\dot{\varepsilon}_{p}$ is equivalent plastic strain rate, $T$ is deformation temperature $\left({ }^{\circ} \mathrm{C}\right)$.

Table 1. Material parameters.

\begin{tabular}{cccc}
\hline Parameters & $\mathrm{T} \leq 900^{\circ} \mathrm{C}$ & $900^{\circ} \mathrm{C}<\mathrm{T}<1000^{\circ} \mathrm{C}$ & $\mathrm{T} \geq 1000^{\circ} \mathrm{C}$ \\
\hline P1 & 33.2951 & $8.40 \mathrm{E}+07$ & $2.66 \mathrm{E}+06$ \\
P2 & -0.00101831 & $-9.28 \mathrm{E}-08$ & -0.00349731 \\
P3 & 0.20143 & 0.234224 & 0.274641 \\
P4 & 0.304404 & -0.354278 & -0.182876 \\
P5 & -0.00181444 & -0.00156227 & -0.00113672 \\
P6 & $-6.06 \mathrm{E}-07$ & -0.000296095 & -0.00104565 \\
P7 & -0.310496 & -0.238207 & 0.159907 \\
P8 & -0.000231895 & 0.000501658 & 0.000328823
\end{tabular}




\subsection{Simulation conditions}

Geometry parameters and processing parameters determined from the actual production line are listed in Table 2. Coulomb bilinear friction model, full Newton-Raphson iterative algorithm and large strain nonlinear procedure are adopted in this model. An equivalent heat transfer coefficient is used to represent radiation and natural convection heat transfer. This model also takes heat generated by friction and plastic deformation into account.

\subsection{Experimental verification}

In order to verify the accuracy of FE model, corresponding rolling experiment is carried out in one Stainless Steel Company. These measured and calculated rolling forces both fluctuate at a level of $30,000 \mathrm{kN}$. To be precise, the average measured rolling force is $28,400 \mathrm{kN}$, while the average calculated value is $29,800 \mathrm{kN}$, and the relative error is less than $5 \%$. Furthermore, the thickness of rolled strip is also measured by means of micrometre, shown as Fig. 3. The measured and calculated strip crown are displayed in Fig. 4 and Table 3. It can be seen from Table 3 that the relative error between measured and calculated strip crown $\mathrm{C}_{\mathrm{w} 40}$ is within $15 \%$. The experiment results are in good agreement with simulated values. Therefore, the proposed FE model is valid. 
Table 2. Simulation conditions.

\begin{tabular}{|c|c|}
\hline Parameters & Value \\
\hline Diameter of back-up roll $(\mathrm{mm})$ & 1424 \\
\hline Barrel length of back-up roll (mm) & 1880 \\
\hline Distance between bearings of back-up roll (mm) & 2730 \\
\hline Chamfer length of back-up roll (mm) & 100 \\
\hline Chamfer height of back-up roll (mm) & 1.5 \\
\hline Diameter of work roll (mm) & 797 \\
\hline Barrel length of work roll $(\mathrm{mm})$ & 1580 \\
\hline Distance between bearings of work roll (mm) & 2880 \\
\hline Width of strip (mm) & 1310 \\
\hline Entry thickness of strip (mm) & 32.6 \\
\hline Exit thickness of strip (mm) & 18 \\
\hline Reduction ratio (\%) & 44.8 \\
\hline Rolling speed $(\mathrm{mm} / \mathrm{s})$ & 1300 \\
\hline Shifting value of work roll (mm) & -32 \\
\hline Bending force of work roll $(\mathrm{kN})$ & 325 \\
\hline Initial temperature of strip $\left({ }^{\circ} \mathrm{C}\right)$ & 980 \\
\hline Initial temperature of rolls $\left({ }^{\circ} \mathrm{C}\right)$ & 60 \\
\hline Friction coefficient & 0.3 \\
\hline Contact heat transfer coefficient $\left(\mathrm{W} \cdot \mathrm{m}^{-2} \cdot \mathrm{K}^{-1}\right)$ & 10000 \\
\hline Equivalent heat transfer coefficient $\left(\mathrm{W} \cdot \mathrm{m}^{-2} \cdot \mathrm{K}^{-1}\right)$ & 170 \\
\hline Ambient temperature $\left({ }^{\circ} \mathrm{C}\right)$ & 20 \\
\hline Inelastic heat fraction & 0.9 \\
\hline Friction heat fraction & 0.9 \\
\hline
\end{tabular}



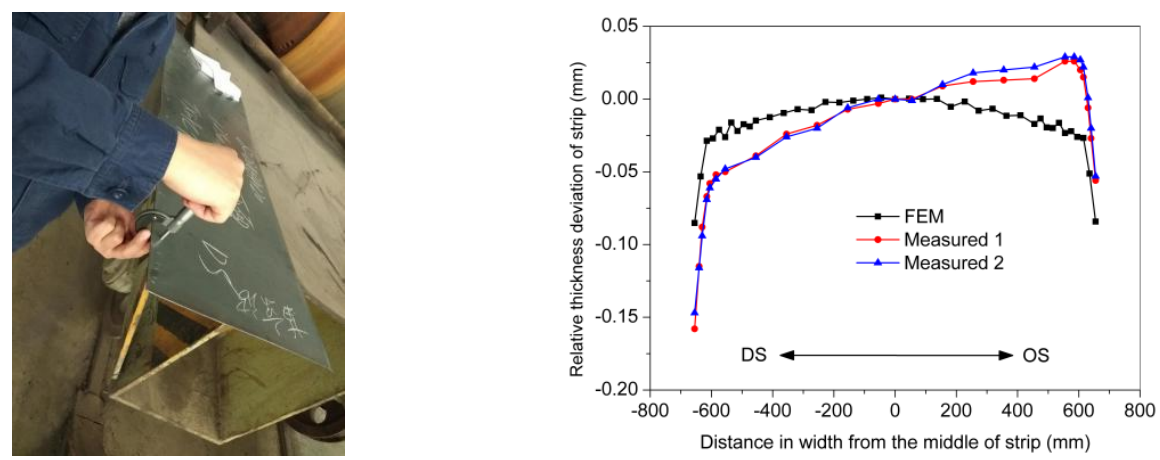

Fig. 3. Measurement of strip thickness. Fig. 4. Comparison with calculated and measured strip crown.

Table 3. Comparison with calculated and measured strip crown.

\begin{tabular}{ccc}
\hline F7 & $\begin{array}{c}\text { Strip crown } \mathrm{C}_{\mathrm{w} 40} \\
(\mu \mathrm{m})\end{array}$ & Relative error \\
\hline FEM & 27.7 & \\
Measured 1 & 26 & $-6 \%$ \\
Measured 2 & 23.5 & $-15 \%$ \\
\hline
\end{tabular}

\section{Discussion and results}

In this part, the influence factors on strip crown, including WR bending force, WR shifting value, BR size, entrance strip crown and rolling force are discussed in detail via the FE model.

\subsection{Effect of work roll bending force on strip crown}

Fig. 5, 6 and Table 4 show the strip crown under various WR bending force. It can be seen that strip crown $\mathrm{C}_{\mathrm{w} 40}$ decreases from $349 \mu \mathrm{m}$ to $176 \mu \mathrm{m}$ when bending force increases from $0 \mathrm{kN}$ to $2000 \mathrm{kN}$, and the influence ratio is -0.0872 .

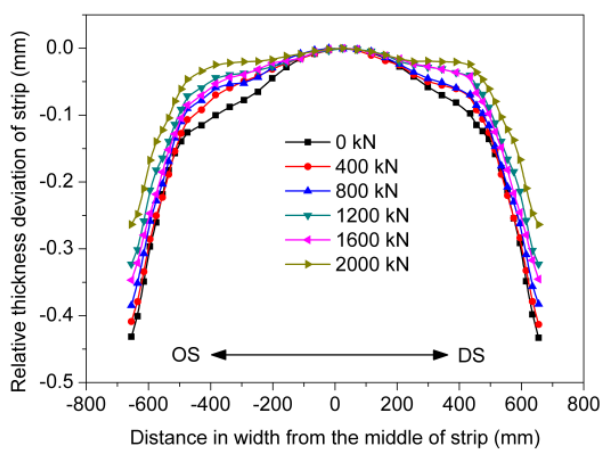

Fig. 5. Strip crown under different bending force.

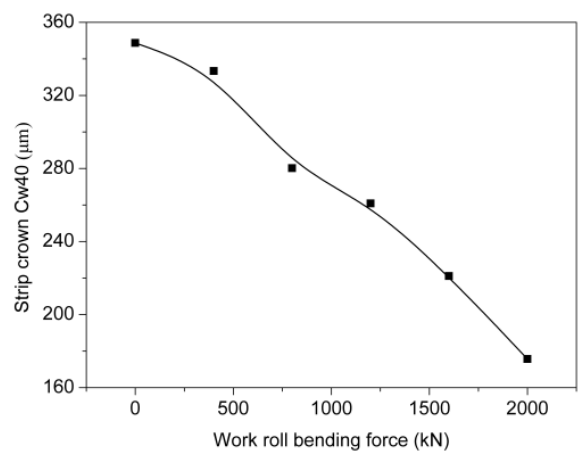

Fig. 6. Effect of bending force on strip crown. 
Table 4. Influence ratio of bending force on strip crown.

\begin{tabular}{ccc}
\hline $\begin{array}{c}\text { Bending force of } \\
\text { work roll }(\mathrm{kN})\end{array}$ & $\begin{array}{c}\text { Strip crown } \mathrm{C}_{\mathrm{w} 40} \\
(\mu \mathrm{m})\end{array}$ & $\begin{array}{c}\text { Influence ratio } \\
(\mu \mathrm{m} / \mathrm{kN})\end{array}$ \\
\hline 0 & 349 & \\
400 & 333 & \\
800 & 280 & -0.0872 \\
1200 & 261 & \\
1600 & 221 & \\
2000 & 176 & \\
\hline
\end{tabular}

\subsection{Effect of work roll shifting value on strip crown}

Fig. 7 and 8 show the strip crown under various WR shifting value. It can be seen from Fig. 7 and 8 that strip crown decreases significantly with the increase of shifting value. Table 5 lists the equivalent crown of WR and strip crown $\mathrm{C}_{\mathrm{w} 40}$ under different WR shifting value. As the CVC roll curve is applied on WR, the equivalent crown of WR is different when WR shifting value varies. It can be found from Table 5 that equivalent crown of WR increases with WR shifting value, and the influence ratio of equivalent crown of WR on strip crown $\mathrm{C}_{\mathrm{w} 40}$ is -1.166 .

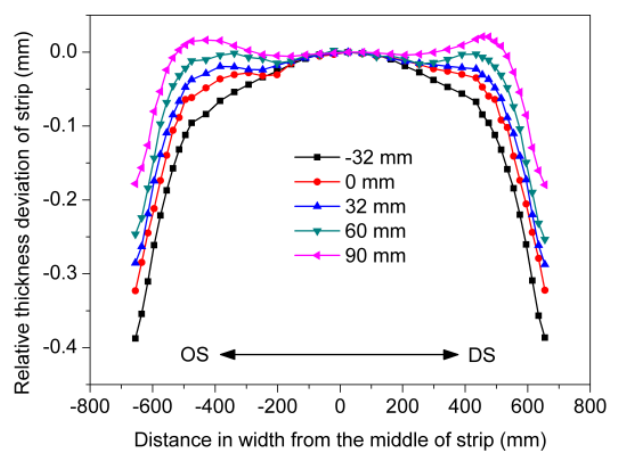

Fig. 7. Strip crown under different shifting value.

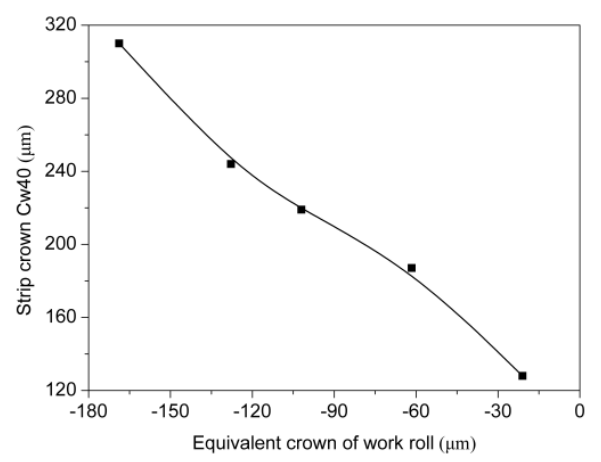

Fig. 8. Effect of WR crown on strip crown.

Table 5. Influence ratio of equivalent crown of work roll on strip crown.

\begin{tabular}{cccc}
\hline $\begin{array}{c}\text { Shift value of } \\
\text { work roll }(\mathrm{mm})\end{array}$ & $\begin{array}{c}\text { Equivalent crown } \\
\text { of work roll }(\mu \mathrm{m})\end{array}$ & $\begin{array}{c}\text { Strip crown } \mathrm{C}_{\mathrm{w} 40} \\
(\mu \mathrm{m})\end{array}$ & $\begin{array}{c}\text { Influence ratio } \\
(\mu \mathrm{m} / \mu \mathrm{m})\end{array}$ \\
\hline-32 & -168.8 & 310 & \\
0 & -127.8 & 244 & -1.166 \\
32 & -102 & 219 & \\
60 & -61.6 & 187 &
\end{tabular}




\subsection{Effect of back-up roll size on strip crown}

Fig. 9, 10 and Table 6 show the strip crown under various diameters of BR. As we can see from Fig. 10 that strip crown $\mathrm{C}_{\mathrm{w} 40}$ decreases with the increase of diameter of BR. This is because the stiffness of BR increases with the increment of BR diameter. To be precise, it can be seen from Table 6 that the variation of $\mathrm{C}_{\mathrm{w} 40}$ is $5.5 \mu \mathrm{m}$ when diameter of BR increases from $1400 \mathrm{~mm}$ to $1520 \mathrm{~mm}$, and the influence ratio is -0.0433 . This is to say, the effect of BR size on strip crown is negligible.

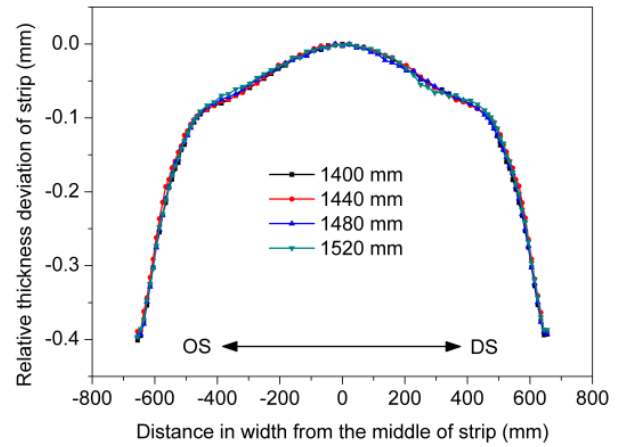

Fig. 9. Strip crown under different BR size.



Fig. 10. Effect of BR size on strip crown.

Table 6. Influence ratio of BR size on strip crown.

\begin{tabular}{ccc}
$\begin{array}{c}\text { Diameter of } \\
\text { work roll }(\mathrm{mm})\end{array}$ & $\begin{array}{c}\text { Strip crown } \mathrm{C}_{\mathrm{w} 40} \\
(\mu \mathrm{m})\end{array}$ & $\begin{array}{c}\text { Influence ratio } \\
(\mu \mathrm{m} / \mathrm{mm})\end{array}$ \\
\hline 1400 & 327.1 & \\
1440 & 327 & -0.0433 \\
1480 & 326.2 & \\
1520 & 321.6 & \\
\hline
\end{tabular}

\subsection{Effect of entrance strip crown on strip crown}

Fig. 11, 12 and Table 7 show the strip crown under various entrance strip crown. As we can see from Fig. 11 and 12 that strip crown $\mathrm{C}_{\mathrm{w} 40}$ increases with the increase of entrance strip crown. To be precise, it can be seen from Table 7 that $\mathrm{C}_{\mathrm{w} 40}$ changes $17 \mu \mathrm{m}$ when entrance strip crown increases from $100 \mu \mathrm{m}$ to $500 \mu \mathrm{m}$, and the influence ratio is 0.0426 . This is to say, entrance strip crown has a small effect on strip crown. 

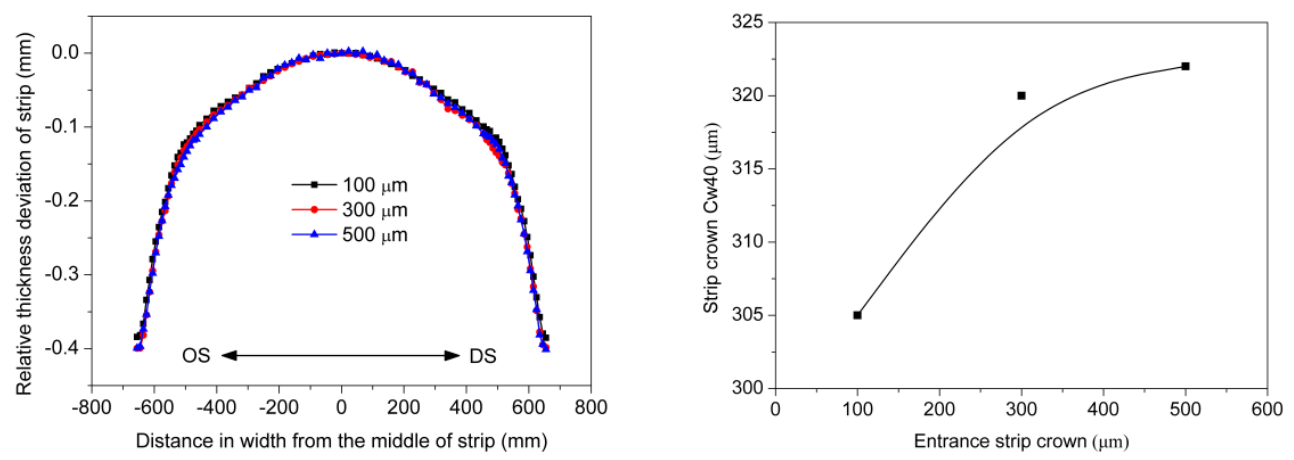

Fig. 11. Strip crown under different entrance strip crown.

Fig. 12. Effect of entrance strip crown.

Table 7. Influence ratio of entrance strip crown on strip crown.

\begin{tabular}{ccc}
\hline $\begin{array}{c}\text { Entrance strip } \\
\text { crown }(\mu \mathrm{m})\end{array}$ & $\begin{array}{c}\text { Strip crown } \mathrm{C}_{\mathrm{w} 40} \\
(\mu \mathrm{m})\end{array}$ & $\begin{array}{c}\text { Influence ratio } \\
(\mu \mathrm{m} / \mu \mathrm{m})\end{array}$ \\
\hline 100 & 305 & \\
300 & 320 & 0.0426 \\
500 & 322 & \\
\hline
\end{tabular}

\subsection{Effect of rolling force on strip crown}

Fig. 13 and 14 show the strip crown under different rolling force. It can be seen from Fig. 13 and 14 that, strip crown increases linearly with the increase of rolling force. Table 8 lists the rolling force and strip crown $\mathrm{C}_{\mathrm{w} 40}$ under various reduction ratio. It can be found from Table 8 that rolling force increases with increasing reduction ratio, and the influence ratio of rolling force on strip crown $\mathrm{C}_{\mathrm{w} 40}$ is 0.0077 , which is about one-tenth of effect of WR bending force on $\mathrm{C}_{\mathrm{w} 40 \text {. }}$

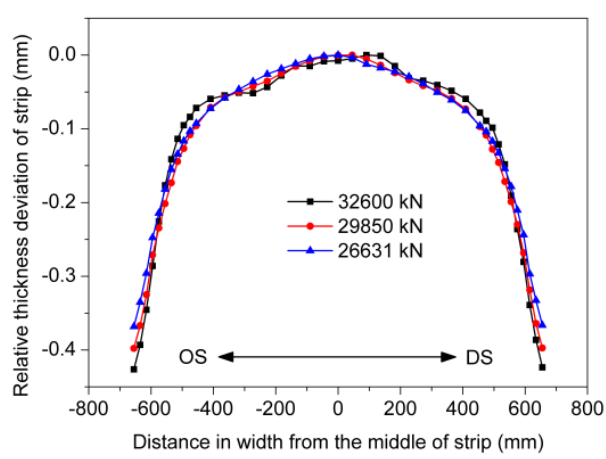

Fig. 13. Strip crown under different rolling force.

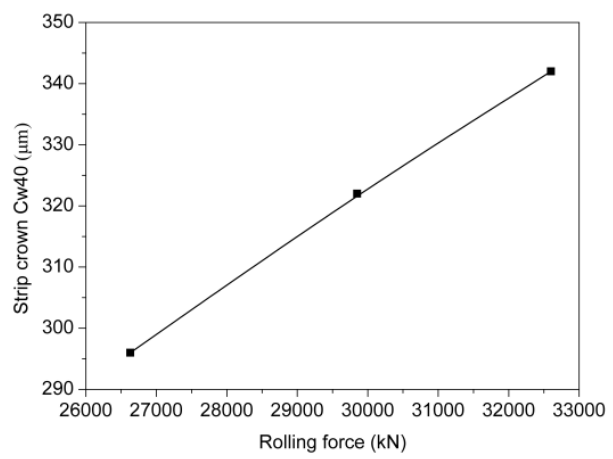

Fig. 14. Effect of rolling force on strip crown.

Table 8. Influence ratio of rolling force on strip crown. 


\begin{tabular}{cccc}
\hline Reduction ratio & $\begin{array}{c}\text { Rolling force } \\
(\mathrm{kN})\end{array}$ & $\begin{array}{c}\text { Strip crown } \mathrm{C}_{\mathrm{w} 40} \\
(\mu \mathrm{m})\end{array}$ & $\begin{array}{c}\text { Influence ratio } \\
(\mu \mathrm{m} / \mathrm{kN})\end{array}$ \\
\hline 0.403 & 26631 & 296 & \\
0.456 & 29850 & 322 & 0.0077 \\
0.511 & 32600 & 342 & \\
\hline
\end{tabular}

\section{Conclusions}

In this study, a 3D elastic-plastic coupled thermo-mechanical FE model is set up to simulate the complicated high-strength strip hot rolling process and then verified experimentally. The influence of bending force and shifting value of WR, BR size, entrance strip crown and rolling force on strip crown has been investigated comprehensively. The following results can be obtained:

(1) With the increase of bending force and shifting value of WR, strip crown decreases markedly.

(2) With the increment of diameter of BR, strip crown decreases slightly. By contrast, strip crown increases marginally with increasing of entrance strip crown. BR size and entrance strip crown exert a tiny influence on strip crown.

(3) Strip crown $\mathrm{C}_{\mathrm{w} 40}$ increases linearly with the increment of rolling force.

The authors would like to thank the financial support from Research Institute of Technology of HBIS Group, China.

\section{References}

[1] J.W. Zhao, Z.Y. Jiang. Rolling of advanced high strength steels: theory, simulation and practice. Taylor \& Francis Group, (2017).

[2] K.. Yamada, S. Ogama, S. Hamau, ISIJ Int. 31, 566 (1991).

[3] P. Gratacos, P. Montmitonnet, C. Fromholz, J.L. Chenot, Int. J. Mech. Sci. 34, 195 (1992).

[4] Z.Y. Jiang, X.L. Liu, X.H. Liu, G.D. Wang, Int. J. Mech. Sci. 42, 693 (2000).

[5] Z.Y. Jiang, A.K. Tieu, J. Mater. Process. Technol. 117, 146 (2001).

[6] T. H. Kim, W. H. Lee, S. M. Hwang, ISIJ Int. 43, 1947 (2003).

[7] G. Zhang, H. Xiao, C. Wang, J. Iron and Steel Res. Int. 13, 23 (2006).

[8] K.Z. Linghu, Z.Y. Jiang, J.W. Zhao, F. Li, D. Wei, J. Xu, X.M. Zhang, X.M. Zhao, Int J Adv Manuf Technol. 74, 1733 (2014). 
[9] K.Z. Linghu, Z.Y. Jiang, F. Li, J.W. Zhao, M. Yu, Y.Q. Wang, Advanced Materials Research. 988, 257 (2014).

[10] A. Aljabri, Z.Y. Jiang, D.B. Wei, Advanced Materials Research. 1061-1062, 515 (2015).

[11]Q.L. Wang, J. Sun, Y.M. Liu, P.F. Wang, D.H. Zhang, Int J Adv Manuf Technol. 92, 1371 (2017).

[12] Q.L. Wang, J. Sun, X. Li, Y.M. Liu, P.F. Wang, D.H. Zhang, Journal of Manufacturing Processes. 34, 637 (2018).

[13] X.D. Wang, F. Li, B. Li, L. Dong, B. Zhang, ISIJ Int. 52, 1637 (2012). 